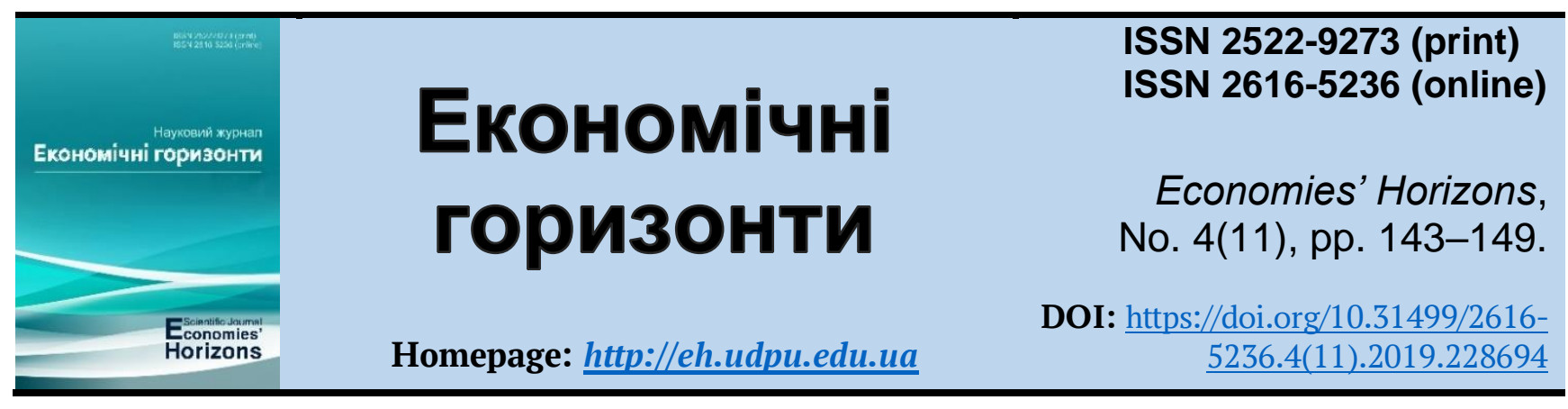

UDC 330.1

\title{
Theoretical features and principles of risk management in the activities of an industrial enterprise
}

\begin{abstract}
Received: 10 November 2019 activities of an industrial enterprise", Economies' Horizons, no. 4(11), pp. 143-149, doi: https://doi.org/10.31499/2616-5236.4(11).2019.228694

Accepted: 12 December 2019

\author{
Alla L. Idobayeva ${ }^{1}$ \\ Idobayeva, A. L. (2019), "Theoretical features and principles of risk management in the
}

Abstract. The purpose of the research. The main purpose of the article is to improve the conceptual apparatus of the risk management process in the activities of an industrial enterprise, the principles of risk management, stages and principles of this process in the activities of an industrial enterprise. Methodology. To improve the conceptual apparatus of the risk management process, the principles of risk management, stages and principles of this process in the activity of an industrial enterprise are used by the following methods: generalization, analysis and synthesis. Results. As a result of the study, an actual definition of the category of "risk management," the stages of risk management and the principles of risk management process, taking into account the modern features of this process, as well as the features of industrial enterprises. Also, as a result of the study, circumstances that do not allow to effectively use worked out and well-established themselves in other areas of activity evaluation and risk management. Practical meaning. The practical significance of the study is the applied nature of the proposed conceptual apparatus, the principles of risk management, stages and principles of this process that can be used in the process of risk management in the activity of an industrial enterprise, which are particularly relevant in a changing and crisis environment in which industrial enterprises operate, and also allows the enterprise to create and develop competitive products, maintain the required level of stability and efficiency. Prospects for further research. The further researches of the author will be devoted to this. Another direction of subsequent developments will be the development of methodological provision of risk management process in the activities of an industrial enterprise.
\end{abstract}

Keywords: risk management, process, industrial enterprise, principle, stage.

JEL Classification: B41, D01, D21.

Number of references: 11; number of tables: 0; number of figures: $\mathbf{0}$; number of formulas: $\mathbf{0 .}$

\footnotetext{
${ }^{1}$ Interregional Academy of Personnel Management; postgraduate; ORCID ID: http://orcid.org/0000-0001-90788345; e-mail:rvps1973@gmail.com.
} 


\title{
Теоретичні особливості та засади управління ризиками в діяльності промислового підприємства
}

\author{
Алла Леонідівна Ідобаєва ${ }^{1}$
}

Стаття надійшла: 10.11.2019 Стаття прийнята: 12.12.2019
Idobayeva A. L. Theoretical features and principles of risk management in the activities of an industrial enterprise. Економічні горизонти. 2019. № 4(11). С. 143149. DOI: $\underline{10.31499 / 2616-5236.4(11) .2019 .228694}$

Анотація. Мета дослідження. Головною метою статті є вдосконалення понятійного апарату процесу управління ризиками в діяльності промислового підприємства, засад управління ризиками, етапів та принципів даного процесу в діяльності промислового підприємства. Методологія. Для вдосконалення понятійного апарату процесу управління ризиками, засад управління ризиками, етапів та принципів даного процесу в діяльності промислового підприємства використано такі методи: узагальнення, аналізу та синтезу. Результати. В результаті проведеного дослідження розроблено власне визначення категорії «управління ризиками підприємства», етапи здійснення управління ризиками та принципи процесу управління ризиками, що враховують сучасні особливості даного процесу, а також особливості діяльності промислових підприємств. Також, в результаті проведеного дослідження, визначено обставини, що не дозволяють ефективно використовувати відпрацьовані i добре зарекомендували себе в інших сферах діяльності методи оцінки і управління ризиками. Практичне значення дослідження полягає у прикладному характері запропонованого понятійного апарату, засад управління ризиками, етапів та принципів даного процесу, які можуть бути використані в процесі управління ризиками в діяльності промислового підприємства, що особливо актуально в умовах мінливого та кризового середовища, в якому функціонують промислові підприємства, а також дозволяє підприємству створювати та розвивати конкурентні продукти, підтримувати необхідний рівень стабільності та ефективності. Перспективами подальших досліджень стане розробка методологічного забезпечення процесу управління ризиками в діяльності промислового підприємства.

Ключові слова: управління ризиками, процес, промислове підприємство, принцип, етап.

Кількість джерел: 11; кількість таблиць: 0; кількість рисунків: 0; кількість формул: 0.

\section{Introduction.}

In the market in conditions of instability and a rapidly changing situation, any enterprise needs to take into account all possible consequences from the actions of competitors and changes in the market conditions, that is, from existing and potential risks and threats. The risk analysis allows project participants to take measures to protect against possible losses. At the same time, created at this moment the theoretical and methodological base of risk management of enterprises is quite limited both in terms of research objects, and in terms of types of risks that are in the centre of attention.
At present, the risk management of the enterprise is mainly focused on managing risks consequences than on identifying and analysing their possible reasons and sources, that is, not preventive management. The argument in favour of this approach is that it is impossible to track all potential sources of risks, to identify all factors of each risk, so it is more advisable to prepare properly to possible adverse effects, plan measures to quickly exit the crisis situation with the least losses. It is for the creation of methods and tools for solving this practical problem aimed at many efforts of many risk management methodologists. And in this regard, it is necessary predominantly as follows: the methods of risk assessment, above

\footnotetext{
Міжрегіональна академія управління персоналом; здобувач; ідентифікатор

ORCID: http://orcid.org/0000-0001-9078-8345; e-mail: rvps1973@gmail.com.
} 
all, in terms of calculating the projected consequences for the enterprise, methods of compensating for these consequences, as well as methods of organizing risk management systems that allow efficiently from crisis situations. It would seem that this is quite enough to ensure the stability of the functioning and development of any business. However, the practice of enterprises in various spheres of the economy indicates the opposite: crisis, bankruptcy and fall markets do not stop, but only amplify.

\section{Literature review.}

The basic concept of risk management process, the principles of risk management, stages and principles of this process in the activity of an industrial enterprise are developed by such foreign scientists as V. Kunin (2011), D. Maksimov and M. Khalikov (2012) V. Stupakov and G. Tokarenko (2005), etc. Among domestic researchers, it is worth distinguishing such authors I. Blank (2005), T. Andreeva and T. Petrovskaya (2005), E. Konovalov and O. Mironov (2013), V. Kravchenko (2008), I. Sinus and O. Gavrik (2015), N. Skopenko and O. Pyanko (2014), V. Vollinsky and G. Velikivanenko (2004).

\section{Methodology.}

In the study of the conceptual apparatus of the risk management process in the activities of an industrial enterprise, the principles of risk management, stages and principles of this process in the activity of an industrial enterprise are used: generalization and analysis in the process of researching the features and essence of the risk management process, definitions of domestic and foreign scholars, in the process The definition of circumstances that do not allow to effectively use worked out and well-proven themselves in other areas of activity assessment and risk management, and synthesis in the process of developing its own definition, the principles of risk management, stages and principles of this process in the activities of an industrial enterprise.

\section{Research objectives.}

The main purpose of the study is to improve the conceptual apparatus of the risk management process in the activities of an industrial enterprise, the principles of risk management, stages and principles of this process in the activities of an industrial enterprise.

\section{Results and discussions.}

Entrepreneurial structures are increasingly experiencing an increasingly aggressive effect of the external environment (crisis) in the form of uncertainty, in which it is impossible to definitely plan their actions to any perspective. In this case, the continuing globalization of the world economy and its crisis character only enhance this aggressive influence of the environment directly to the company. The recent global financial crisis and the crisis caused by coronavirus and the recession associated with it clearly identified the weaknesses of many enterprises that underestimated their risks. At present, more and more entrepreneurs begin to realize that in the current unstable economic situation, it is possible to win in a competitive struggle only in the presence of a comprehensive approach to risk management.

As a result, in modern society, the economic resource becomes an adequate response to uncertainty and risk, and the key to the successful functioning of any enterprise - the ability to manage risks, that is, to make optimal management decisions. At the same time, the ability to predict risks and lay them up to decisions that take into account possible expenses growth, at the stage of the project contributes to the successful development of the enterprise. The experience of leading international companies operating in the industrial sphere is convincingly proved that the stability of business development and improvement of management efficiency is impossible without the active use of risk management tools as an integral part of the company's management system, regardless of its size, scales and specifics of production or services. The actualization and importance of rapid introduction in Ukrainian enterprises risk management can confirm the following arguments:

First, domestic enterprises require economic and legal independence, not only financial and industrial, but also due to lack of state support, politicians in the event of accidents, strikes or other difficulties; 
Secondly, the dependence of local budget revenues from the effectiveness of enterprises in their territory;

Thirdly, an increase in the number and severity of the consequences of large industrial accidents, which is explained by excessive depreciation of fixed assets; non-perfect mechanisms for ensuring the safety of the population and territories from industrial accidents and disasters;

Fourth, insufficiency of efficient management experience in the enterprise in crisis and growing role of financial markets for economies of the world and the latter - the processes of globalization are accompanied by the emergence of new risks.

At the same time, it should be noted that "the risk management of the enterprise" is rather complex and multifaceted, but, with a systematic and integrated concept, resulting in a certain universal definition of this concept. As a result of the analysis of the definitions of this concept, it is possible to distinguish the following main features of the risk management process, which are allocated and by which it is carried out by a majority of domestic and foreign scholars:

- risk management of the enterprise as a special direction of managerial sector of the enterprise;

- risk management as a scientific discipline;

- management of business risks as an assessment system;

- management of the company's risks as a system of relations aimed at reducing uncertainty in the situation of a particular selection;

- Management of company risk as a complex, multi-stage process or type of activity, which includes the following successive measures and actions: development of the general philosophy of risk management of the enterprise, their detection, analysis, assessment, the purpose of which is decreasing and neutralizing negative consequences;

- risk management as a process of developing and implementing various methods, recommendations, measures that allow to predict the emergence of risk and reduce its degree;
- Management of business risks as art and science on ensuring the conditions for successful functioning of any production and economic unit in risk conditions (in a broad sense); The process of developing and implementing a program for reducing any random losses (a risk management program at the level of enterprise) covering two stages: preliminary (study of all necessary to compile a risk management program, information and acceptance of certain decisions) and the main (development of a defined management program. certain types of risks);

- Management of business risks as changes in the enterprise, changes in its environment and (or) goals in such a way as to change the overall tendency of the company to risk - from risks-negatives to risks-positives.

In view of the above, we developed an actual definition of the category "risk management," according to which is a continuous management process aimed at providing the necessary level of reliability and safety of the enterprise, achieving strategic and tactical goals and landmarks by monitoring and evaluating existing and potential calls, threats and risks, prejudice, neutralization, elimination, minimizing their negative impacts and consequences, maximizing opportunities.

At the same time, during risk management, it is necessary to take into account the peculiarities of the sphere in which the enterprise operates - it also applies to industrial enterprises. Thus, at the present stage of development, the following main features of industrial entrepreneurship can be distinguished:

1. The situation is unstable, so one of the well-known distribution laws cannot be involved, which includes the use of statistical laws;

2. With the help of an existing mathematical toolkit, an informal risk analysis and potential threats to the enterprise cannot be carried out;

3. Owners and managers seek primarily to obtain a risk management plan, not data on its value. That is why modern tools must ensure a decrease in uncertainty and increase the reliability of predictions on the activities of the enterprise in all spheres; 
4. The proposed methods of diversification risk management can reduce the risk of the production sphere as a whole, rather than a specific assortment group of goods or services. Moreover, the development of a new product or service increases the level of risk, so diversification as a risk management method does not work;

5. In modern conditions, enterprises work for short-term prospects, and therefore, timely techniques for reducing risks in the short-term period are much more important for the enterprise, but a long-term strategy, which is based on the main focus of management;

6. More clear differentiation of decisionmaking methods on risk factors (operational, financial and investment) for the enterprise are more effective in the conditions of uncertainty;

7. Monitoring and risk analysis is important at all stages of production activities of the enterprise, in particular, the choice of production program, sources of financing, productive investment assessment, the efficiency of resources use in external and internal risks, etc.

For industrial enterprises, which are key business entities, the formation of a risk management system is one of the most important elements of ensuring the effectiveness of this activity and competitive development of the enterprise. At the same time, not always owners and managers of enterprises are deeply understanding the all the severity of the negative consequences associated with the lack of such a system, and are ready to bear the necessary costs for its creation and implementation at their enterprise. Decision of tasks of identifying mechanisms for generating risks and assessing the severity of their consequences is an essential element of changing the existing stereotype underestimation of the importance of the formation of a risk management system as a factor in improving the efficiency of entrepreneurial activity. In addition, during the management of the risks of an industrial enterprise, it is necessary to take into account the fact that industrial enterprises are influenced by macroeconomic risks common to the entire state industry (currency risk, inflation, political) and specific risks of this industry. In addition to sectoral risks for each enterprise there are also individual risk factors. Therefore, considering the areas of influence of risk factors, we can say that external risks of the enterprise are a set of sectoral and national risks, while internal risks are most often individual for each industrial enterprise.

Given the above-mentioned, industrial risk management - this continuous management process is aimed at providing the necessary level of reliability and safety of the enterprise, achieving strategic and tactical goals and landmarks by monitoring and evaluating existing and potential challenges, threats and risks, bias, neutralization, elimination, minimizing their negative impacts and consequences, maximizing opportunities.

To date, a number of reference models of risk management of enterprises are developed, among which the following are the following:

- ISO 31000: 2009 "Risk Management Principles and Recommendations";

- ISO 31010: 2009 "Risk Management, Risk Assessment Technology";

- ISO / IEC 73: 2009 "Risk Management: Terminology";

- AS / NZS 4360: 2004: Risk Management, etc.

These standards are aimed at assisting enterprises in developing its own approaches to risk management, but they do not reflect the risk management features in the field of quality assurance of products produced and are required to certify.

Patriotic scientists V. Waterinsky and G. Velikovanenko allocated seven general and rather broad stages of risk management process:

1) an information and analytical stage, which makes it possible to assess the emergence of the entire set of risks, regardless of whether the enterprise will be able to pour on them in the event of their implementation;

2) the identification stage during which the possible parameters of all probable risks are established; 
3) the stage of integrated (quantitative and qualitative) analysis of risks with the calculation of their possible impact on the functioning of the management object;

4) stage of planning actions to reduce risk degree;

5) the stage of controlling the possible or existing situation;

6) the stage of implementing an action program in case of risk;

7) Stage analysis and proposals for the future (Vitlinskyy and Velykoivanenko, 2004).

Some similar list of stages gives $\mathrm{V}$. Kravchenko: definition of risk context: mission, strategic and organizational purposes; identifying risks and their description; risk assessment: probability and value of consequences; ranking and choice of risks; Influence on risk: methods and strategy; economic risk management efficiency (Kravchenko, 2008).

T. Andreeva and T. Petrovskaya in the work "Risk in a market economy" distinguish nine consecutive stages of risk management process: complete set, identification, verification, qualitative and quantitative analysis, risk decrease, response planning, control, response, promising analysis. An interesting feature of these steps is that they represent an infinite cycle in which the last stage goes into the first and all starts again. (Andryeyeva and $\mathrm{Pe}$ trovska, 2005).

Based on a detailed study of reference risks management models, as well as positions and development of specialists in the field of effective risk management at an industrial enterprise, it is possible to distinguish the following stages in the risk management system: determining the risk management area; choice of the method of calculating risks and forecast of the value of losses from the event of a risk event; analysis of operating personnel instructions in part of its behaviour in the event of an emergency to which risks can lead to; development of managerial decisions to minimize risk; creation of a risk management strategy; Monitoring risks.

The issue of determining the principles of risk management of industrial enterprises also reflected in the writings of many scholars. Thus, according to I. Blanca, the process of financial risks of the enterprise is based on the following principles: the financial manager must deliberately take risks if it intends to obtain an appropriate income from the implementation of a financial transaction; The financial risks portfolio should consist of those risks to which methods of neutralization can be applied; Financial losses according to various types of risks do not depend on each other, so all risks should be neutralized separately; When managing financial risks from an alternative selection of such a solution that ensures the greatest efficiency and financial security; The management process should take into account the financial philosophy of the enterprise, which is reflected in impairment, neutrality or risk propensity.

I. Sinus and O. Gavrik distinguish the following basic principles on which the risk management should be carried out: the possibility of transferring risks; reasonable risk taking; comparison of the level of risks taken with profitability; the cost-effectiveness of risk management; taking into account the time factor (Svynous and Havryk, 2015).

According to Y. Konovalov, risk management process is associated with decisionmaking and requires compliance with such principles: command; Informativeness; prediction; Integration of risk management in general activities; documentation (Konovalov and Myronov, 2013).

According to the results of the study of the positions of various scientists and taking into account the features of industrial enterprises, we consider it necessary to allocate the following basic principles for which the risk management of industrial enterprises should be carried out:

- integration - implies the possibility of flexible response and adaptation of the entire risk management system before new types and risk factors, threats;

- the continuity of functioning - suggests that the risk management process coincides over time with the activities of the enterprise;

- timeliness - involves the implementation of risk management procedures in accordance with this time;

- Information sufficiency - involves informing the risk manager only if necessary; 
- continuous improvement of the organization of the system - implies permanent selfdevelopment of units of the enterprise;

- modelling - involves the division of the enterprise into separate processes and modelling of various situations;

- adoption by employees the least risky decisions - suggests that each employee of the enterprise can act as a risk manager and should be interested in making less risky decisions.

\section{Conclusions.}

Consequently, it can be argued that from the effectiveness of the risk management process of an industrial enterprise depend to a large extent not only its future prospects, potential. Opportunities and capacity, but also the possibility of functioning of the enterprise as a convictable market entity at a suitable period of time in a particular market situation. Risk management will enable the company not only minimize possible losses from a specific agreement or operation, but also for their professional implementation of the opportunity to adopt an optimal decision on the choice of directions of activity of the enterprise and obtain the maximum possible profit for a particular market situation. Also, future explorations of the author will enable the development of methodological provision of risk management process in the activities of an industrial enterprise.

\section{References}

Andryeyeva, T. Y. and Petrovska T. Y. (2005), Ryzyk u rynkoviy ekonomitsi [Risk in a market economy], Burun, Kharkiv, Ukrayina, 128 p.

Blank, I. A. (2005), Financial Risk Management, Nika Center, Kyiv, Ukraine, 600 p.

Konovalov, Y. O. and Myronov, O. V. (2013), “Risk management system: Concepts, functions, components”, Innovatsiyna ekonomika, no. 9, pp. 127-132.

Kunin, V. A. (2011), Industrial risk management (theory, methodology, practice), Publishing House of St. Petersburg Academy of Department and Economics, St. Petersburg, Russia, 184 p.

Kravchenko, V. A. (2008), "Program of business management risk: Contents and stages of development", available at: http://www.nbuv.gov.ua/e-journals/PSPE/2008-1/Kravchenko 108.

Maksimov, D. A. and Khalikov, M. A. (2012), Assessment methods and strategies to ensure the economic security of the enterprise, CJSC "Grykh and K", Moscow, Russia, 220 p.

Svynous, I. V. and Havryk, O. Y. (2015), "Theoretical principles of forming a system of risk management system, innovative economy”, Innovatsiyna ekonomika, vol. 4, pp. 76-80.

Skopenko, N. S. and Pyankova, O. V. (2014), "Theoretical and methodological principles of risk management as an instrument of management of economic risk, economics and organization of management”, Ekonomika i orhanizatsiya upravlinnya, vol. 1(17), pp. 235-243.

Stupakov, V. S. and Tokarenko, G. S. (2005), Risk management, finance and statistics, Moscow, Russia, 248 p.

Starostina, A. O. and Kravchenko, V. A. (2004), Ryzyk-menedzhment: teoriya ta praktyka [Risk management: Theory and practice], IVTS "Vydavnytstvo "Politekhnika", Kyiv, Ukraine, 200 p.

Vitlinskyy, V. V. and Velykoivanenko, H. I. (2004), Ryzykolohiya v ekonomitsi ta pidpryyemnytstvi [Risk in economics and entrepreneurship], KNEU, Kyiv, Ukraine, 480 p.

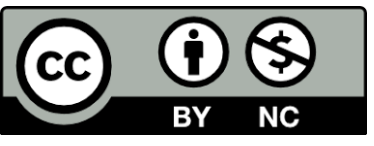

Цей твір ліцензовано на умовах Ліцензії Creative Commons «/з Зазначенням Авторства = Некомериійна 4.0 Міжнародна» (CC BY-NC 4.0). This is an open access journal and all published articles are licensed under a Creative Commons "Attribution-NonCommercial 4.0 International" (CC BY-NC 4.0). 